\title{
Spatial exploration, dendrometric characteristics and prediction models of wood production in a stand of Acacia schaffneri in Durango, Mexico
}

\author{
Luis Manuel Valenzuela Nuñez ${ }^{*}$, Aldo Rafael Martínez Sifuentes ${ }^{2}$, \\ José Antonio Hernández Herrera ${ }^{3}$, Cristina García de la Peña ${ }^{1}$, Edwin Amir Briceño Contreras ${ }^{1}$, \\ Julio César Ríos Saucedo ${ }^{4}$, Enrique Melo Guerrero ${ }^{5}$
}

${ }^{1}$ Laboratorio de Biología y Ecología Forestal, Facultad de Ciencias Biológicas, Universidad Juárez del Estado de Durango, Av. Universidad S/N, Fracc. Filadelfia, Gómez Palacio, Durango, C. P. 35010, Mexico

${ }^{2}$ INIFAP Centro Nacional de Investigación Disciplinaria en la Relación Agua Suelo Planta Atmósfera, Km. 6.5 Margen Derecha Canal de Sacramento, Gómez Palacio, Durango, C. P. 35140, Mexico

${ }^{3}$ Departamento de Recursos Naturales, Universidad Autónoma Agraria Antonio Narro, Calzada Antonio Narro 1923, Buenavista, Saltillo, Coahuila, C. P. 25315, Mexico

${ }^{4}$ INIFAP Campo Experimental Valle del Guadiana, Carr. Durango - El Mezquital km. 4, Durango, Durango, C. P. 34170, Mexico

${ }^{5}$ Instituto de Ciencias Agropecuarias, Universidad Autónoma del Estado de Hidalgo, Avenida Universidad Km. 1 s/n Exhacienda Aquetzalpa, Tulancingo de Bravo, Hidalgo, C. P. 43600 , Mexico

\begin{abstract}
Valenzuela Nuñez, L.M., Martínez Sifuentes, A.R., Hernández Herrera, J.A., García de la Peña, C., Briceño Contreras, E.A., Ríos Saucedo, J.C., Melo Guerrero, E., 2022. Spatial exploration, dendrometric characteristics and prediction models of wood production in a stand of Acacia schaffneri in Durango, Mexico. Folia Oecologica, 49 (1): 70-79.

Degraded vegetation is the result of a process that affects structural and functional characteristics. Tree species from the Acacia genus are very important to the ecosystem in semi-arid lands due to their participation in the recovery of highly degraded areas. One of the most important species among this genus is $A$. schaffneri. The status of a forest stand is determined according to its structure, including height, stratum and density. Remote sensing is a valuable method for estimating volumetric stocks and associated changes in forest populations over established periods of time. The objective of this research was to estimate wood volume of A. schaffneri using remote sensing, and to complement that information with the results obtained from an estimation method based on forest measurements. The results obtained showed that the crown area was the dendrometric variable that can be used in a wood volume prediction model. In the exploratory analysis between dendrometric variables and remote sensing showed low and negative associations were observed in the four stations analyzed. There are conservation problems due to anthropogenic activities, among which stands out the intensive grazing that results in a decrease of the natural regeneration capacity of Acacia schaffneri.
\end{abstract}

\section{Keywords}

degradation, forest mensuration, grazing, prediction models

\footnotetext{
*Corresponding author:
} 


\section{Introduction}

Forest resources of arid zones are an important economic source for the inhabitants of these regions who obtain sustainment and raw materials for food production. Among those forest resources are tree species from the Acacia genus, which are very important to the ecosystem due to their participation in the recovery of highly degraded arid areas. Degraded vegetation is the result of a process that affects structural and functional characteristics. Forest degradation occurs as a result of human activities, which in turn are driven by a variety of macroeconomic, demographic, technological, institutional and political factors (TAYLOR and HALPERN, 1991; Borreli and Oliva, 2001; AJBilou et al., 2003; StanturF et al., 2014; VÁsQUEZ-GrANDON et al., 2018). Acacia species have been reported that contribute to soil retention (KASAYE et al., 2020) and remediation of heavy metal polluted soil (LANDERos-Márquez et al., 2011), and are highly resistant to fire and drought (GómEZ-ACEVEDo and TAPIA-PASTRANA, 2003; RZEDOWSKI and CALDERÓN-DE RzEDOWSKI, 2003). Besides, Acacia trees are also used for fuel (Nugroho-Marsoem and IraWati, 2016), cattle feed, (GeBeYew, 2015), essential oil production (PAPAeFTHIMIOU et al., 2017), and tannery industry (ADIGUZEL-ZENGIN et al., 2017). All botanical parts of Acacia species contain anti-inflammatory and anti-carcinogenic compounds (Delgadillo-Puga et al., 2018; Lin et al., 2018).

One of the most important species among this genus is A. schaffneri, which is distributed from southern United States to central Mexico along with other Acacia species; however, it is not considered as invasive. (VAliente-BANUet et al., 2000; Machuca-Velasco et al., 2017). A. schaffneri can be either a bush or a tree up to $6 \mathrm{~m}$ high (RZEDOwSKI and CALDERÓN-DE RZEDOWSKI, 2003) forming a forest stand, which is a set of trees or other forest vegetation that occupies a certain area and is uniform in their species composition, age distribution, quality and thickness to differentiate itself from the rest of the mass or vegetation that surrounds it. The status of a forest stand is determined according to its structure, including height, stratum and density (VÁSQUEZ-GRANDON et al., 2018). Regarding that, remote sensing is a valuable method for estimating volumetric stocks and associated changes in forest populations over established periods of time (RosenQvist et al., 2003; TiмотнY et al., 2016; IsSA et al., 2020). Previous studies have analyzed the response of spectral indices (RSI) obtained from Sentinel-2 in the estimation of aerial biomass (WANI et al., 2015; HUANG et al., 2016). However, it is advisable to complement the information obtained using RSI with direct field sampling and biomass estimation methods based on dendrometric variables (Torre-Tojal et al., 2019; DunCANSON et al., 2020). Some of the advantages of using RSI include that it facilitates the monitoring of forest populations and biophysical components, changes in land use; and also helps in the determination of scenarios in a reliable manner (BEDÓN and PINTO, 2007). In addition, this method can be applied to monitor large areas (GómEz et al., 2016).

A. schaffneri is highly exploited in rural areas in
Northern Mexico, including the state of Durango; therefore, it is required to establish the structure and volumetric stocks in this state. The objective of this research was to estimate wood volume of $A$. schaffneri using remote sensing (Response of Spectral Indices), and to complement that information with the results obtained from an estimation method based on forest measurements.

\section{Materials and methods}

\section{Study area}

The study was carried out in a 1,200-ha natural stand of Acacia schaffneri in Cuencamé, Durango (northern México), located at the coordinates $24^{\circ} 25^{\prime} 53.09^{\prime \prime} \mathbf{N}$, $103^{\circ} 50^{\prime} 41.28^{\prime \prime} \mathrm{W}$ with an elevation of 2,020 m (Fig. 1) within a central plateau physiographic province consisting of plains formed by alluvial deposits interrupted by mountain ranges and isolated elevations, most of them from volcanic origin. The predominant soils are rendzina and kastanozem. The region climate is temperate semi dry $(\mathrm{BS} 1 \mathrm{kw}(\mathrm{w}))$ having a cold Winter and Summer rain, with an annual average temperature of $16.5{ }^{\circ} \mathrm{C}$ and an accumulated annual rainfall of $526.6 \mathrm{~mm}$ (GARCÍA, 1998). The predominant vegetation in the region mainly consists of arboreal and shrubby species of the Fabaceae family along with natural and induced grassland (INEGI, 2016).

\section{Stand characteristics}

Characterization of dendrometric variables was performed using a systematic sampling within stratified sampling units from 20 conglomerates $\left(400 \mathrm{~m}^{2}\right)$ in the Acacia schaffneri stand, according to the recommendations of the National Forestry Commission (COMISIÓN NACIONAL FORESTAL, 2015). The variables measured were tree height, crown area and stem diameter at breast height; height was determined using a clinometer considering an established distance (LÓPEZ-LÓPEZ, 2005) with the following equation:

$H=(A+B) * C$,

where $\mathrm{H}$ is the tree height $(\mathrm{m})$; $\mathrm{A}$ is the reading at the crown top (degrees); B is the reading at the stem base (degrees); and $\mathrm{C}$ is the distance from the clinometer to the tree $(\mathrm{m})$.

The crown area was estimated based on the largest diameter and the perpendicular diameter using the following equation:

$$
C A=L D * M D * 0.7854 \text {, }
$$

where CA is the crown area $\left(\mathrm{m}^{2}\right)$; $\mathrm{LD}$ is the larger diameter $(\mathrm{m})$; and $\mathrm{MD}$ is the minor diameter $(\mathrm{m})$.

\section{Usable wood volume}

Acacia pruned logs are relatively short in length and cylindrical shape (BORN and CHOJNACKY, 1985). ROMAHN et al. (1994) propose the determination of the usable wood volume using the Huber method (RIAÑo and LizARAZO, 2017) following this equation: 


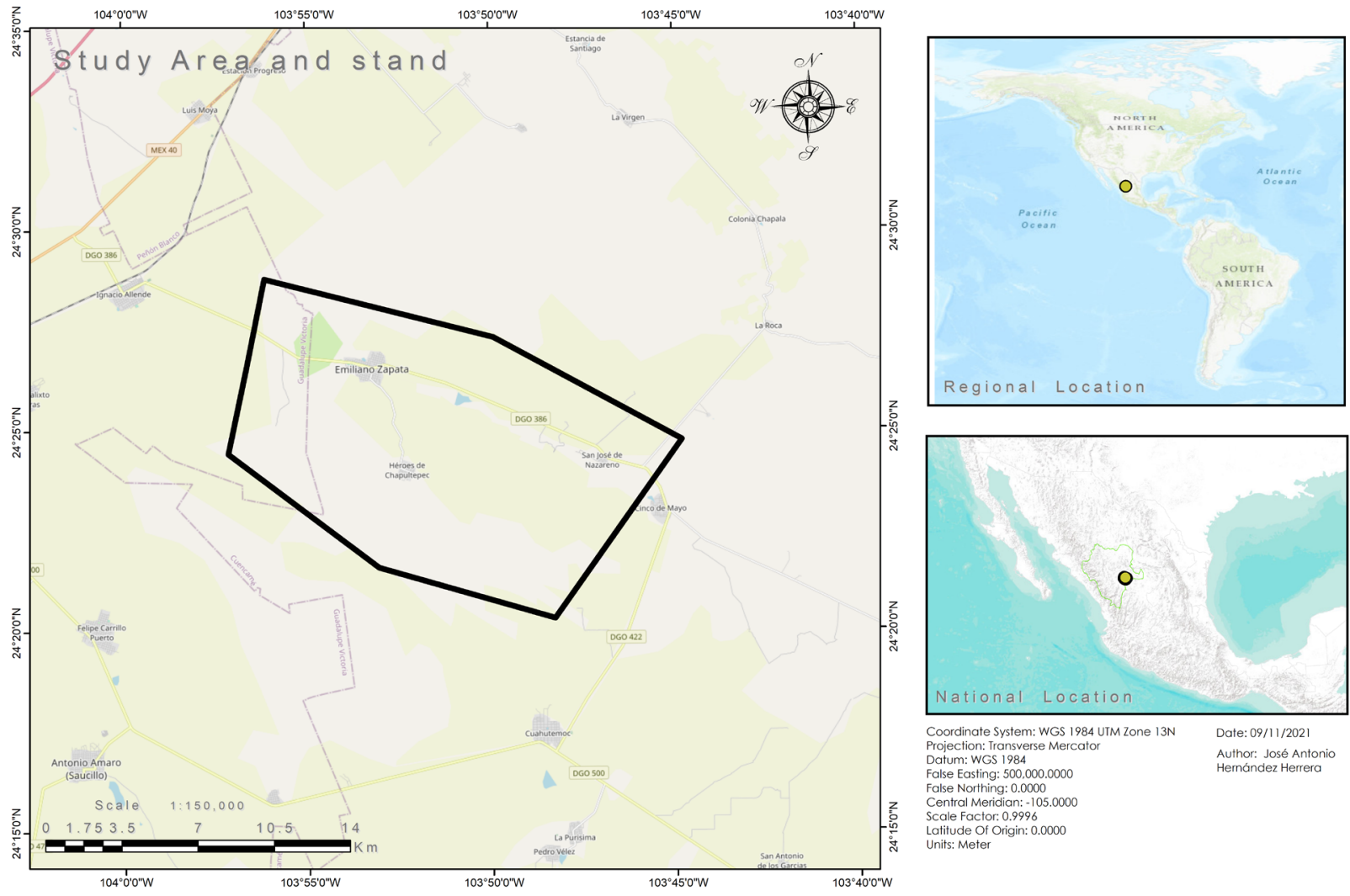

Fig. 1. Map of the study area in Cuencame, Durango (Mexico).

$V=A m * L$,

where $\mathrm{V}$ is the usable wood volume $\left(\mathrm{m}^{3}\right), \mathrm{Am}$ is the log middle section area $\left(\mathrm{m}^{2}\right)$, and $\mathrm{L}$ is the log length $(\mathrm{m})$.

Satellite images (Sentinel-2) and spectral indices obtention

The images used in this study were obtained from Earth Explorer portal of the United States Geological Survey (USGS), through the link https://earthexplorer.usgs.gov/. The Sentinel-2 mission of the European Space Agency (ESA) provides high resolution images, allowing to improve the available multispectral data services, such as the Landsat and SPOT missions (DENG et al., 2019). The Sentinel-2 mission consists of two satellites, and has a temporal resolution of 5 days, with 13 spectral bands located between the spectral region of visible to shortwave infrared which are as follows: four bands of $10 \mathrm{~m}$ of spatial resolution, six bands of $20 \mathrm{~m}$, and three bands of $60 \mathrm{~m}$, with a sweep width of $290 \mathrm{~km}$ (ESA, 2016). The Sentinel-2 mission incorporates three bands in the rededge region, which allows to run spatial studies related to nutritional and stress conditions for plant covers (DELGADO et al., 2011; López-CALDERón et al., 2020).

The dates of the downloaded images contemplated the four seasons of the year 2019: for Spring on April $3^{\text {rd }}$, Summer on July $17^{\text {th }}$, Fall on October $10^{\text {th }}$, and for Winter on February $7^{\text {th }}, 2020$. Images selected had zero concentration of cloudiness to avoid interferences while working with reflectance. Atmospheric correction was performed by the Dark Object Subtraction method (DOS) (CHavez, 1996), using the Semi-Automatic Classification Plugin in the software QGIS 3.14. Seven spectral indices were generated in order to prove if the information obtained by remote sensing can be used to generate estimation models of dendrometric variables in Acacia logs from the Sentinel-2 images. The six spectral indices generated are presented in Table 1.

\section{Statistical analysis}

The statistical analysis of the present study consisted of two phases: In the first phase a prediction model was developed using Acacia logs dendrometric data, in order to estimate the volume of usable wood by mean of a Principal Component Analysis (PCA) (Olivares, 2014). The prediction model was developed once it was established the variable with the largest influence $(p<0.05)$ using Principal Components Analysis correlations. The second phase consisted in determining the possible relation between the dendrometric variables measured in field, the usable wood volume of Acacia logs, and derivatives of spectral indices and the 13 bands of each satellite image. The relation was verified by mean of a correlation of Pearson $(\mathrm{p}<0.05)$ using the CorrPlot library in R 3.4.3 environment R 3.4.3 (R CORE TEAM, 2015). 
Table 1. Spectral indices used to establish association with dendrometric data and usable wood volume in an Acacia schaffneri stand of Cuencame, Durango (Mexico)

\begin{tabular}{|c|c|c|}
\hline Index & Equation & \\
\hline GCI; Green Coverage Index & $\mathrm{GCI}=\left(\frac{\mathrm{B} 09}{\mathrm{~B} 03}\right)-1$ & GiteLSON, 2005 \\
\hline SAVI; Soil-Adjusted Vegetation Index & $\mathrm{SAVI}=\frac{(\mathrm{B} 08-\mathrm{B} 04)}{(\mathrm{B} 08+\mathrm{B} 04+0.428) *(1.428)}$ & HuETE, 1988 \\
\hline AVI; Advanced Vegetation Index & $\mathrm{AVI}=[\mathrm{B} 08 *(1-\mathrm{B} 04) *(\mathrm{~B} 08-\mathrm{B} 04)]^{1 / 3}$ & DEKA et al., 2012 \\
\hline EVI; Enhanced Vegetation Index & $\mathrm{EVI}=\frac{2.5 *(\mathrm{~B} 08-\mathrm{B} 04)}{((\mathrm{B} 08+6 * \mathrm{~B} 04-7.5 * \mathrm{~B} 02)+1))}$ & HuETE et al., 2002 \\
\hline $\begin{array}{l}\text { NDVI; Normalized Difference } \\
\text { Vegetation Index }\end{array}$ & $N D V I=\frac{(B 08-B 04)}{(B 08+B 04)}$ & TUCKER, 1979 \\
\hline LAI; Leaf Area Index & $L A I=\frac{\operatorname{Ln} \frac{0.69-S A V I}{0.59}}{0.91}$ & $\begin{array}{l}\text { GITELSON et al., } \\
2003\end{array}$ \\
\hline
\end{tabular}

\section{Results and discussion}

\section{Stand characteristics}

The height distribution of the measured $A$. schaffneri trees presented the highest percent $(55.5 \%)$ of the class ranging from 2 to $4 \mathrm{~m}$, while the percent of trees was gradually decreasing in the remaining classes (Fig. 2). The smallest height class ( 1 to $2 \mathrm{~m}$ ) had a low frequency percent (6.9\%), meanwhile it was observed there were no trees higher than $9 \mathrm{~m}$. The diameter categories from 20 to $40 \mathrm{~cm}$ had $47 \%$ of the measured Acacia logs, while the thinnest categories $(0-20 \mathrm{~cm})$ had $33.34 \%$ of the log samples, and none of the logs had a diameter of $80 \mathrm{~cm}$ thick. The structural characteristics of the vegetation subjected to anthropic alterations (without silvicultural criteria and objectives) of determined intensity and frequency can alter a stand structure, and eventually it will reflect the alteration degree in the stand (VÁsQUEZ-GRANDON et al., 2018).

The categorical analysis of tree diameter describes the stand demographic status, and also provides of the presence of conservation problems (AJBILOU et al., 2003). Tree diameter distribution is a method to determine uniformity and characteristics of a stand for forest inventories (AsSMANN, 1970). A low percent of individuals of small diameter indicates there is no population regeneration (LóPEZ-SáNCHEZ et al., 2020; TAYLOR and HALPERN, 1991). Distribution of tree diameter in a stand must have a single peak with distortion to the left despite forest management (ZHENG and ZHOU, 2010; De Lima et al., 2017). The Acacia stand does not present this pattern of tree diameter distribution (Fig. 2) because it has been subjected to a hard anthropic intervention mostly by an intensive grazing which compromises the stand regeneration capacity (BORRELI and Oliva, 2001). The Acacia stand has an unimodal diametric tree distribution with a high percentage of trees with intermediate trunk diameter, indicating a recent decline in the normal regeneration rate of the stand, which can result in a short term aging of the tree population (AJBILOU et al., 2003).

\section{Principal Component Analysis (PCA)}

The PCA indicates that the usable wood variable (UW) is highly associated to the crown area (CA), with a correlation rate of $0.79(p<0.05$, Fig. 3). On the other hand, low correlations were found between the UW and $\log$ diameter (Di) $(r=0.51)$, and between $\mathrm{UW}$ and $\mathrm{H}$ (height), with a $r=0.05$

The model generated that can be used to estimate usable wood volume by mean of the crown area is as follows (Fig. 4):

$$
Y=0.0015 * X+0.0017
$$

where $\mathrm{Y}$ is the usable wood volume $\left(\mathrm{m}^{3}\right)$, and $\mathrm{X}$ is the crown area $\left(\mathrm{m}^{2}\right)$.

The calculation of the estimated usable wood volume using the obtained model resulted similar to that observed using the dendrometric variables measured on the field (Fig. 5). The model validation parameters can be considered as adequate for all criteria (Table 2).

The exploratory analysis between the dendrometric variables and the usable volume of Acacia logs with the generated indices and spectral bands (Fig. 6) mostly showed low and negative associations for the four stations analyzed. Some of the highest positive correlations were: AC and B07_VER ( $\mathrm{r}=0.22), \mathrm{Al}$ and GCI_INV 

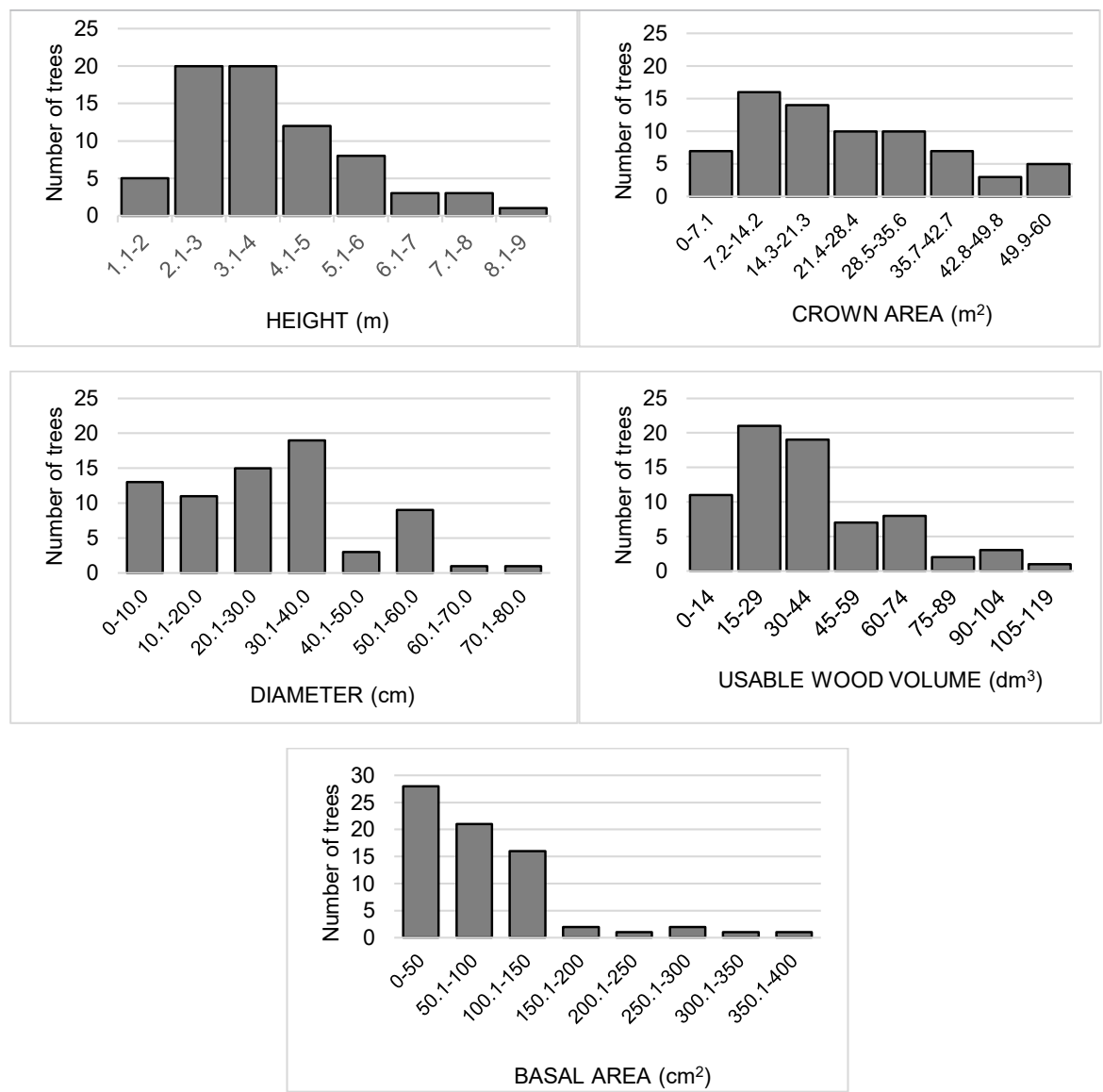

Fig. 2. Characterization of dendrometric variables of an Acacia schaffneri stand of Cuencame, Durango (Mexico).

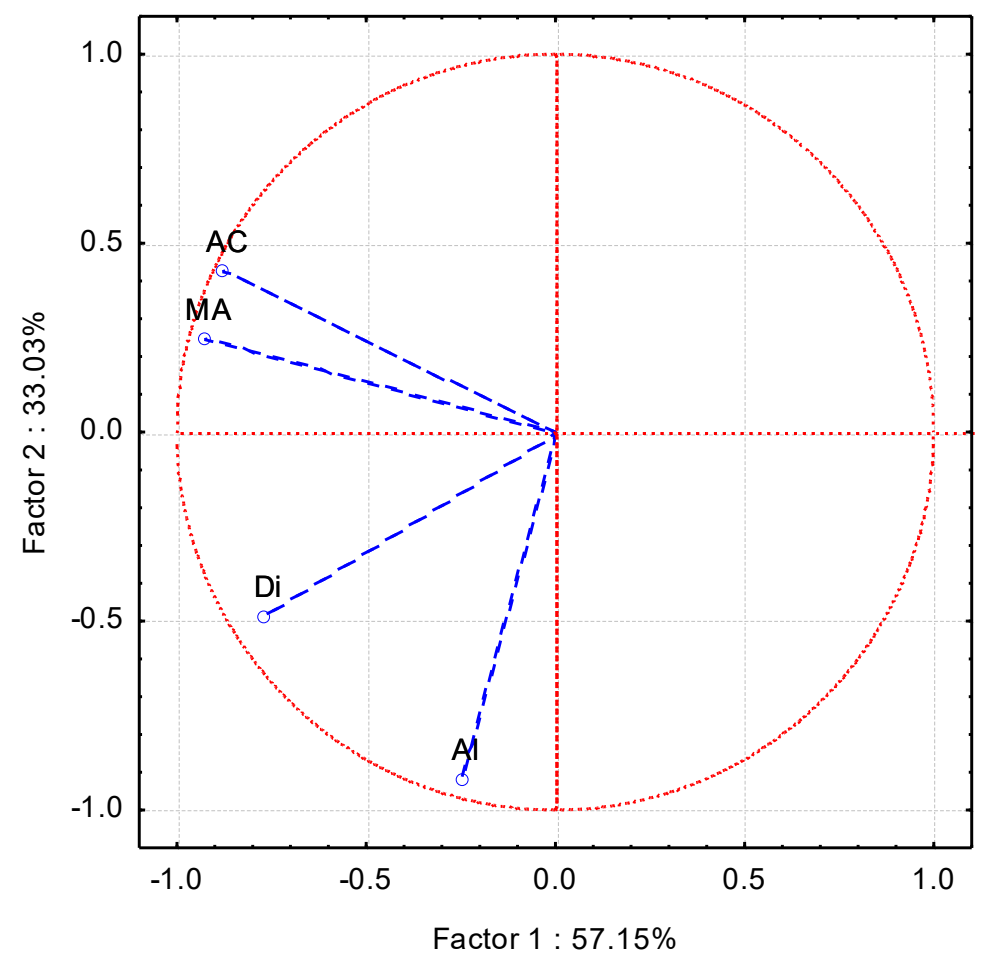

Fig. 3. Principal Component Analysis between dendrometric variables and usable wood volume of an Acacia schaffneri stand of Cuencame, Durango (Mexico). 


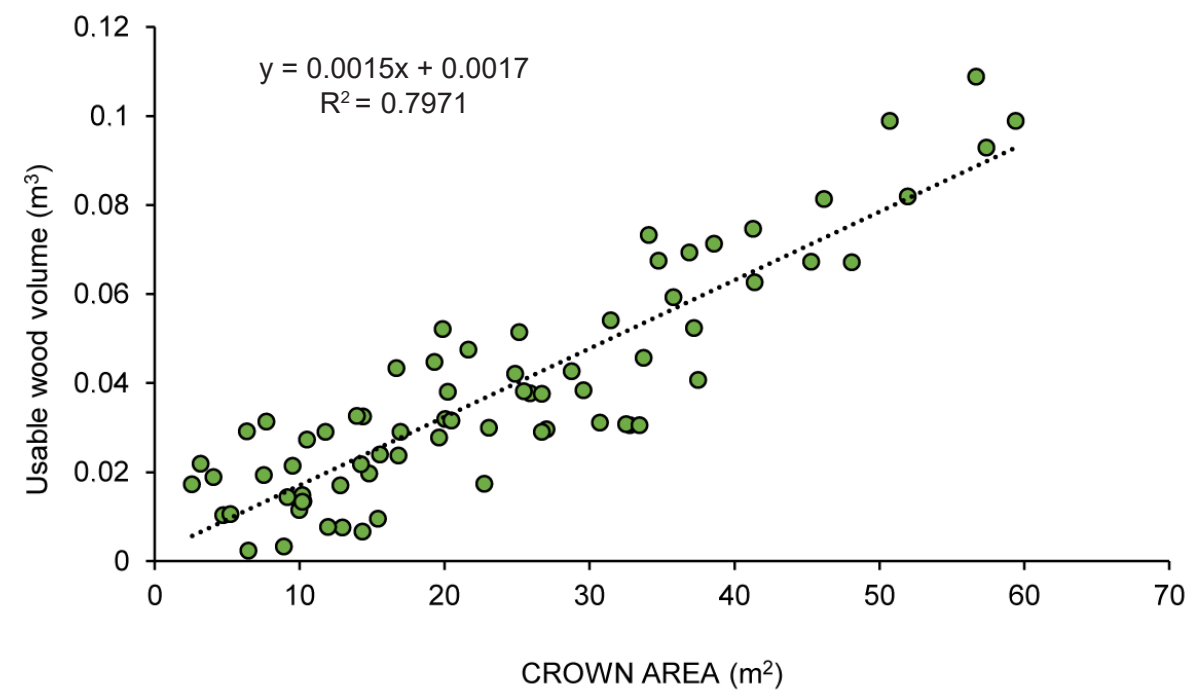

Fig. 4. Dispersion plot between the values of usable wood and crown area for an Acacia schaffneri stand of Cuencame, Durango (Mexico).

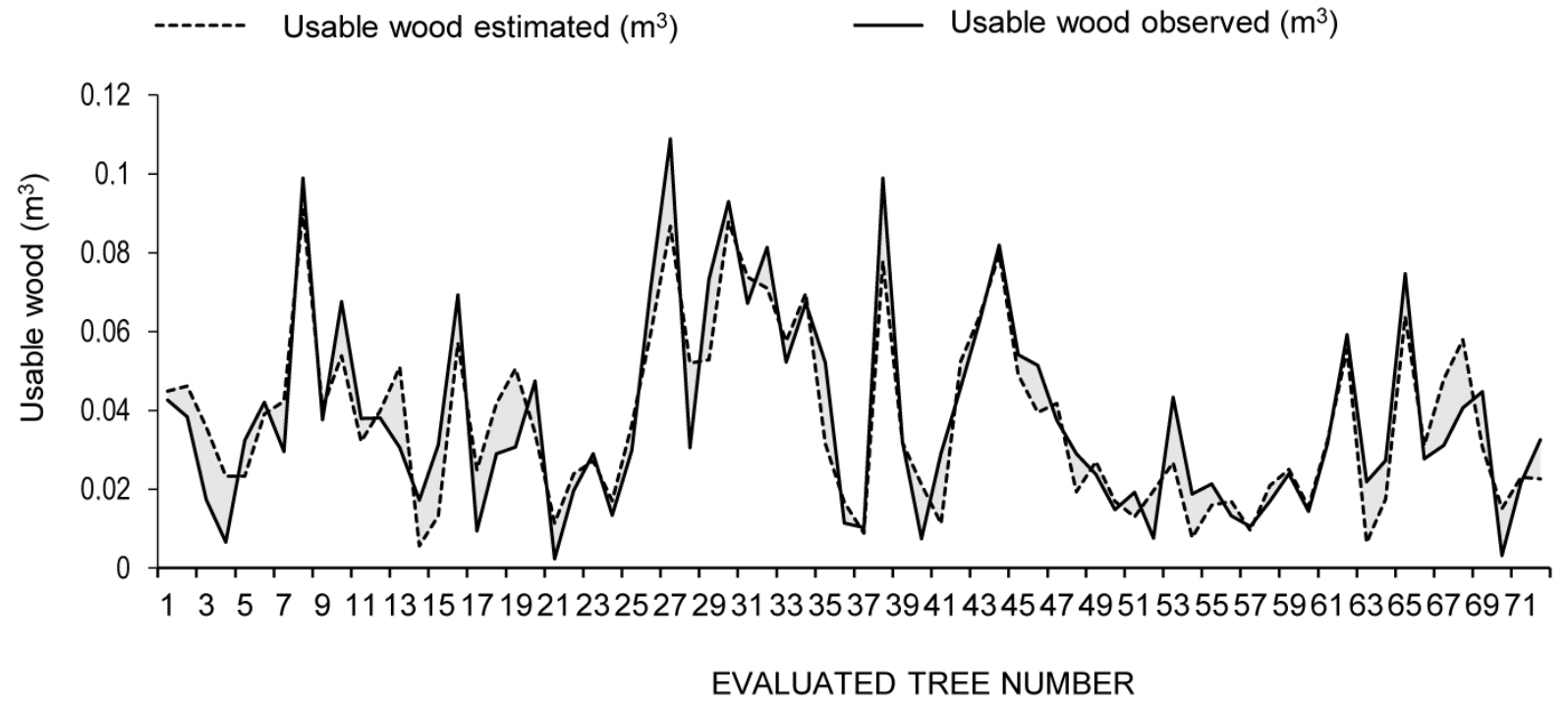

Fig. 5. Estimated and observed values of usable wood volume of an Acacia schaffneri stand of Cuencame, Durango (Mexico).

$(\mathrm{r}=0.31)$, DI and B10_VER $(\mathrm{r}=0.27)$, MA and AVI_OTO $(r=0.19)$. On the other hand, the highest negative correlations $(\mathrm{p}<0.05)$ were: $\mathrm{AC}$ and B01_OTO $(\mathrm{r}=-0.19), \mathrm{Al}$ and B02_INV $(\mathrm{r}=-0.29)$, DI and AVI INV $(r=-0.22)$, MA and B01_OTO $(r=-0.29)$. Previous studies have analyzed the response of spectral indices obtained from Sentinel-2 in the estimation of aerial biomass (WANi et al., 2015; HUANG et al., 2016). AsKAR et al. (2018) reported that the NDI 45 and the EVI allow to estimate the aerial biomass in Acacia auriculiformis with an $\mathrm{R}^{2}$ of 0.81 . Although the correlations and consequently the determination coefficient $\mathrm{R}^{2}$ in the present study are much lower, the response of the dendrometric variables of Acacia stand addresses to the red border spectrum and to the red spectrum with the AVI index.

\section{Conclusions}

Several forest problems including anthropic intervention by intensive grazing compromise the natural regeneration capacity of Acacia schaffneri populations. Crown area is a dendrometric variable that can be used for establishing a wood volume prediction model. The exploratory analysis between dendrometric variables and remote sensing using RSI showed low and negative associations in the evaluations performed in all four annual seasons. It is required further evaluation of these two evaluation methods in order to obtain wood volume prediction models in arid zones stands. 
Table 2. Model validation parameters of the estimated usable wood volume obtained from the dendrometric data of crown area in an Acacia schaffneri stand of Cuencame, Durango (Mexico)

\begin{tabular}{lll}
\hline Statistics & Calibration & Verification \\
\hline Pearson correlation & $0.88^{*}$ & $0.89^{*}$ \\
Error reduction & $0.77^{*}$ & $0.83^{*}$ \\
Value of "t" & $4.04^{*}$ & $7.16^{*}$ \\
Sign test & $7^{*}$ & $5^{*}$ \\
First significant difference & $5^{*}$ & $8^{*}$ \\
Durbin-Watson coefficient & 2.19 & 2.18 \\
Efficiency coefficient & 0.76 & 0.82 \\
\hline
\end{tabular}

$* \mathrm{p} \leq 0.05$

\section{Spring}

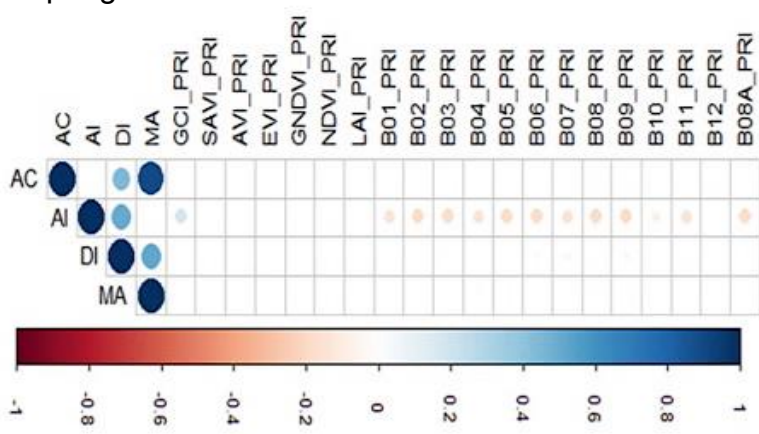

\section{Summer}

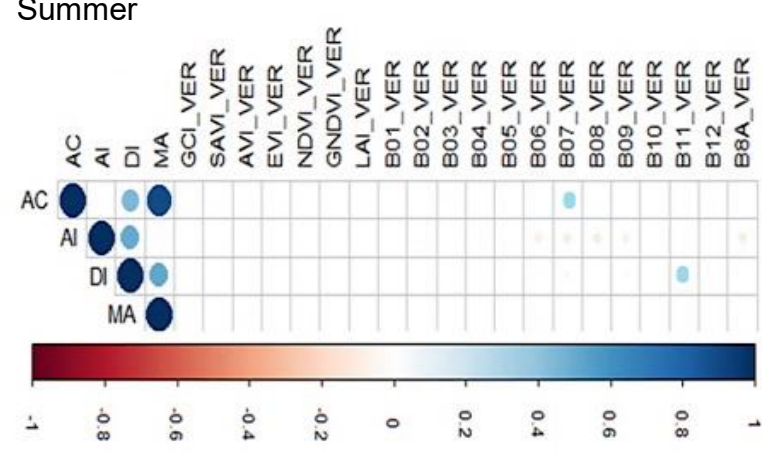

\section{Fall}

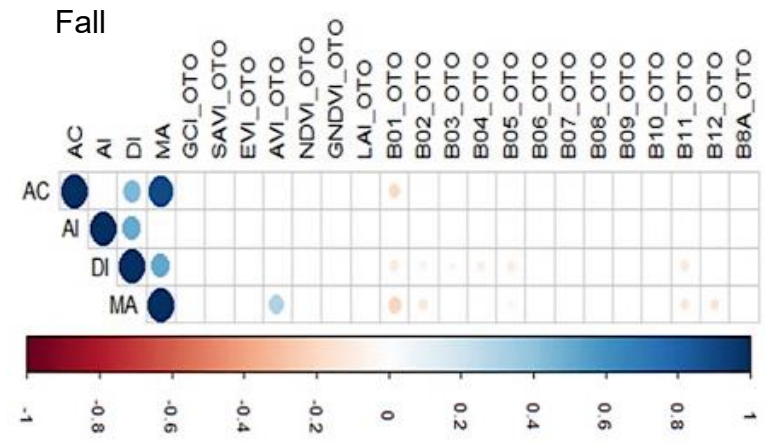

Winter
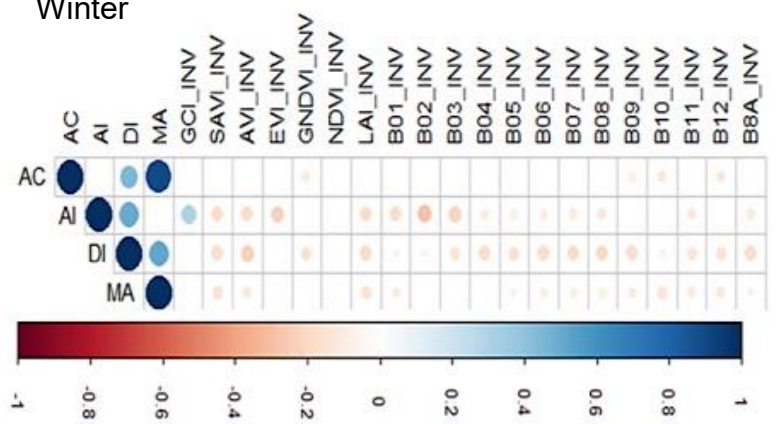

Fig. 6. Exploratory analysis between the dendrometric variables and the obtained values of usable wood volume using spectral indices and bands of an Acacia schaffneri stand of Cuencame, Durango (Mexico).

\section{Acknowledgements}

The authors express our gratitude to the civilian population and rural authorities of Cuencame, Durango, Mexico for the permits granted for data collection. We are grateful to Julia Núñez Contreras and Eugenia Valenzuela Núñez for the support and facilities to provide food and room. Furthermore, we thank to the students Josue de la Cruz Ramos, María Guadalupe Torres Hernandez and Uriel Calderon Villegas for their support in data collection.

\section{References}

Adiguzel-Zengin, A.C., Zengin, G., Kilicarislan-OzKan, C., Dandar, U., Kilic, E., 2017. Characterization and application of Acacia nilotica L. as an alternative vegetable tanning agent for leather processing. Fresenius Environmental Bulletin, 26 (12): 7319-7326.

Ajbilou, R., Marañón, T., Arroyo, J., 2003. Distribución de clases diamétricas y conservación en el norte de Marruecos [Diameter class distribution and conservation in northern Morocco]. Investigación Agraria: Sistemas y Recursos Forestales, 12 (2): 111-123.

Askar, A., Nuthammachot, N., Phairuang, W., Wicaksono, P., Sayektiningsih, T., 2018. Estimating aboveground biomass on private forest using Sentinel-2 Imagery. Journal of Sensors, 2018: Article ID 6745629, 11 p. https://doi.org/10.1155/2018/6745629

Assmann, E., 1970. The principles of forest yield study. Oxford: Pergamon Press. 504 p.

Bedón, P.P., Pinto, A.A., 2007. Evaluación de técnicas de detección de cambios del uso de la tierra a través del análisis multitemporal de imágenes satelitales en el Cantón Daule [Evaluation of techniques to detect changes in land 
use through multitemporal analysis of satelite images established for the area of the district Daule]. [cit. 202106-24].www.repositorio.espe.edu.ec/bitstream/21000/ 514/2/T-ESPE033066-A.pdf

Born, D.J., ChoJnACKy, D.C., 1985. Woodland tree volume estimation: A visual segmentation technique. Research Paper INT-344. Ogden, Utah: U.S. Department of Agriculture, Forest Service, Intermountain Forest and Range Experiment Station. 16 p. https://doi.org/10.5962/ bhl.title. 69074

Borreli, P., Oliva, G., 2001. Efectos de los animales sobre los pastizales [Effects of animals on grasslands]. In Borreli, P., Oliva, G. (eds). Ganadería sustentable en la Patagonia Austral. Santiago, Chile: INTA, p. 99-128.

Chavez, P.S., 1996. Image-based atmospheric corrections revisited and improved photogrammetric engineering and remote sensing. Photogrammetric Engineering and Remote Sensing, 62: 1025-1036.

COMISIÓN NACIONAL FORESTAL, 2015. Inventario Nacional Forestal y de Suelos. Procedimientos de muestreo [National Forest and Soil Inventory. Sampling procedures]. Guadalajara, Jal., México: CONAFOR.

De Lima, R.B., Bufalino, L., Alves Júnior, F.T., Da Silva, J.A.A., FerreIRA, R.L.C., 2017. Diameter distribution in a Brazilian tropical dry forest domain: Predictions for the stand and species. Anais da Academia Brasileira de Ciências, 89 (2): 1189-1203. [cit. 2021-06-02]. https:// www.redalyc.org/articulo.oa?id=32751197036.

Deka, J., TriPAThI, O.P., Khan, M.L., 2012. Implementation of forest canopy density model to monitor tropical deforestation. Journal of Indian Society of Remote Sensing, 41: 469-475. https://doi.org/10.1007/s12524012-0224-5

Delgadillo-Puga, C., Cuchillo-Hilario, M., Navarro -Ocaña, A., Medina-Campos, O.N., Nieto-Camachoa, Ramírez-Apan, T., López-TeCpoyotl, Z.G., Díaz-Martínez, M., Álvarez-Izazaga, M.A., Cruz-Martínez, Y.R., SÁNCHEZ-QuEZADA, V., GómEZ-Franciscoe, TORREVillalvazo, I., Furuzawa-Carballedaj, CamachoCoronam, R., Pedraza-Chaverri, J., 2018. Phenolic compounds in organic and aqueous extracts from Acacia farnesiana pods analyzed by ULPS-ESI-Q-oa/TOF-MS. In vitro antioxidant activity and anti-inflammatory response in CD-1 mice. Molecules, 23: 2386. https://doi. org $/ 10.3390 /$ molecules 23092386

Delgado, D., Jorge, J., Groffman, P., Nearing, M., Goddard, T., Reicosky, D., Lal, R., Kitchen, N., Rice, C., Towery, D., SAlon, P., 2011. Conservation practices to mitigate and adapt to climate change. Journal of Soil and Water Conservation, 66 (4): 118A-129A. https://doi. org/10.2489/jswc.66.4.118A

Deng, J., Huang, Y., Chen, B., Tong, C., Liu, P., Wang, H., Hong, Y., 2019. A methodology to monitor urban expansion and green space change using a time series of multi-sensor SPOT and Sentinel-2A images. Remote Sensing, 11 (10): 1230. https://doi.org/10.3390/ rs11101230

Duncanson, L., Armston, J., Disney, M., Avitabile, V., Barbier, N., Calders, K., Carter, S., Chave, J., Herold, M., Macbean, N., Mcroberts, R., Minor, D., Paul, K., RéJou-Méchain, M., Roxburgh, S., Williams, M., Albinet, C., Baker, T., Bartholomeus, H., Bastin, J.F.,
Coomes, D., Crowther, T., Davies, S., de Bruin, S., De Kauwe, M., Domke, G., Falkowski, M., Fatoyinbo, L., Goetz, S., Jantz, P., Jonckheere, I., Jucker, T., Kay, H., Kellner, J., Labriere, N., Lucas, R., Morsdorf, F., Phillips, O.L., Quegan, S., SaAtchi, S., SchaAf, C., Schepaschenko, D., Scipal, K., Stovall, A., Thiel, C., Wulder, M.A., Camacho, F., Nickeson, J., Roman, M., Margolis, H., 2020. Global aboveground biomass product validation best practices protocol. Version 1.0. In Duncanson, L., Disney, M., Armston, J., Minor, D., Camacho, F., Nickeson, J. (eds). Best practice protocol for satellite derived land product validation. Land Product Validation Subgroup (Working Group on Calibration and Validation, Committee on Earth Observation Satellites). 222 p. DOI: $10.5067 / \mathrm{doc} / \mathrm{ceoswgcv} / \mathrm{lpv} / \mathrm{agb} .001$

EsA, 2016. European Spatial Agency. Data access, Annual report 2016. [cit. 2021-05-31]. https://sentinels. copernicus.eu/documents/247904/0/Sentinel-DataAccess-Annual-Report-2016/1de5e2b3-c108-4c6f-92401 b8ac9539e33

García, E., 1998. Comisión Nacional para el Conocimiento y Uso de la Biodiversidad. Climatología. [National Commission for the Knowledge and Use of Biodiversity. Climatology]. [cit. 2021-07-02]. http://www.conabio. gob.mx/informacion/gis/

Gebeyew, K., Beriso, K., Mohamed, A., Silassie, G., Melaku, S., Worku, S., 2015. Review on the nutritive value of some selected Acacia species for livestock production in dryland areas. Journal of Advances in Dairy Research, 3: 139. DOI: 10.4172/2329-888X.1000139

Gitelson, A.A., MerzlaK, M.N., Grits, Y., 1996. Novel algorithms for remote sensing of chlorophyll content in higher plant leaves. Papers in Natural Resources, 238. https://doi.org/10.1109/IGARSS.1996.516985

Gitelson, A.A., Viña, A., Arkebauer, T.J., Rundquist, D.C., Keydan, G., LeavitT, B., 2003. Remote estimation of leaf area index and green leaf biomass in maize canopies. Geophysical Research Letters, 30 (5): 1248. https://doi.org/10.1029/2002GL016450

Gitelson, A.A., Viña, A., Ciganda, V., Rundquist, D.C., ARKEBAUER, T.J., 2005. Remote estimation of canopy chlorophyll content in crops. Geophysical Research Letters, 32: L08403. https://doi.org/10.1029/2005GL0 22688

Gómez-Acevedo, S.L., Tapia-Pastrana, F., 2003. Estudio genecológico en Prosopis laevigata, Acacia farnesiana y Acacia schaffneri (Leguminosae) [Genecological study in Prosopis laevigata, Acacia farnesiana and Acacia schaffneri (Leguminosae)]. Darwiniana, 41 (1-4): 47-54 https://www.redalyc.org/articulo.oa?id=66941406

Gómez, C., White, J.C., Wulder, M.A., 2016. Optical remotely sensed time series data for land cover classification: A review. ISPRS Journal of Photogrammetry and Remote Sensing, 116: 55-72. https://doi.org/10.1016/j. isprsjprs.2016.03.008

Huang, C., Ye, X., Deng, C., Zhang, Z., Wan, Z., 2016. Mapping above-ground biomass by integrating optical and SAR imagery: A case study of Xixi National Wetland Park, China. Remote Sensing, 8 (8): 647.

Huete, A.R., 1988. A soil-adjusted vegetation index (SAVI). Remote Sensing of Environment, 25: 295-309. https://doi. org/10.1016/0034-4257(88)90106-X

Huete, A., Didan, K., Miura, T., Rodriguez, E.P., Gao, 
X., Ferreira, L.G., 2002. Overview of the radiometric and biophysical performance of the MODIS vegetation indices. Remote Sensing of Environment, 83: 195-213. https://doi.org/10.1016/S0034-4257(02)00096-2

INEGI, 2016. Carta de uso de suelo y vegetación escala 1:250,000, serie VI [Land use and vegetation chart scale 1: 250,000, series VI]. [cit. 2021-06-17]. http://www. conabio.gob.mx/informacion/gis/

Issa, S., Dahy, B., Ksiksi, T., Saleous, N., 2020. A review of terrestrial carbon assessment methods using geospatial technologies with emphasis on arid lands. Remote Sensing, 12 (12): 2008. https://doi.org/10.3390/ rs 12122008

Kasaye, M., Abebe, G., Abiyu, A., Wondie, M., Belay, B., 2020. Selection of different trees/shrubs species for rehabilitation of degraded lands in Wag-lasta area, Northeastern Ethiopia. Journal of Forest Research, 9: 231. DOI: 10. 35248/2168-9776.20.9.231

Landeros-Márquez, O., Trejo-Calzada, R., RevelesHernández, M., Valdez-Cepeda, R.D., ArreolaÁvila, J.G., Pedroza-Sandoval, S., Ruíz-Torres, J., 2011. Uso potencial del huizache (Acacia farnesiana L. Will) en la fitorremediación de suelos contaminados con plomo [Potential use of huizache (Acacia farnesiana L. Will) in the phytoremediation of lead-contaminated soils]. Revista Chapingo Serie Ciencias Forestales y del Ambiente, 17, Special issue: 11-20. http://www.scielo. org.mx/pdf/rcscfa/v17nspe/v17nspea3.pdf

Lin, H.Y., Chang, T.C., Chang, S.T., 2018. A review of antioxidant and pharmacological properties of phenolic compounds in Acacia confusa. Journal of Traditional and Complementary Medicine, 8 (4): 443-450. https://doi. org/10.1016/j.jtcme.2018.05.002

López-Calderón, M.J., Estrada-Ávalos, J., RodríguezMoreno, V.M., Mauricio-Ruvalcaba, J.E., MartíneZSifuentes, A.R., Delgado-Ramírez, G., Miguel-Valle, E., 2020. Estimation of total nitrogen content in forage maize (Zea mays L.) using spectral indices: Analysis by random forest. Agriculture, 10 (10): 451. https://doi. org/10.3390/agriculture10100451

LóPEZ-LóPEZ, M.A., 2005. Un procedimiento alternativo al tradicional para la medición de alturas con clinómetro [An alternative to the traditional procedure for measuring heights with a clinometer]. Madera y Bosques, 11 (2): 69-77.

López-SÁnchez, C.L., Bolívar-Cimé, B., AparicioRentería, A., Viveros-Viveros, H., 2020. Population structure of Alnus jorullensis, a species used as firewood by five rural communities in a natural protected area of Mexico. Botanical Sciences, 98 (2): 238-247. https://doi. org/10.17129/botsci.2392

Machuca-Velasco, R., Borja-Delarosa, A., CoronaAmbriz, A., Zaragoza-HernándeZ, I., Arreola-Avila, J.G., JimÉnEZ-MACHORRo, J., 2017. Xilotecnia of the wood of Acacia schaffneri from the state of Hidalgo, Mexico. Maderas, Ciencia y Tecnología, 19 (3): 293308. DOI: $10.4067 / \mathrm{S} 0718-221 \mathrm{X} 2017005000025$

Nugroho-Marsoem, S., Irawati, D., 2016. Basic properties of Acacia mangium and Acacia auriculiformis as a heating fuel. In Advances of science and technology for society. Proceedings of the $1^{\text {st }}$ international conference on science and technology 2015. ICST-2015, 11-13
November 2015, Yogyakarta, Indonesia. AIP Conference Proceedings, 1755. Melville, N.Y.: Institute of Physics, 130007-1-130007-7. https://doi.org/10.1063/1.4958551

Olivares, B., 2014. Aplicación del análisis de Componentes Principales (ACP) en el diagnóstico socioambiental. Caso: sector Campo Alegre, municipio Simón Rodríguez de Anzoátegui [Application of the Principal Component Analysis (APC) in the socio-environmental diagnosis. Case: Campo Alegre sector, Simón Rodríguez de Anzoátegui municipality]. Multiciencias, 14 (4): 364 374. [cit. 2021-06-14]. http://produccioncientificaluz.org/ index.php/multiciencias/article/view/19470

Papaefthimiou, E., Vagias, C., Couladis, M., Tzakou, O., 2017. Study of volatile components of Acacia farnesiana Willd. flowers. Record of Natural Products, 11 (5): 474478. http://doi.org/10.25135/rnp.60.17.03.015

R Core Team, 2015. $R$ : A language and environment for statistical computing. Vienna, Austria: R Foundation for Statistical Computing. [cit. 2021-06-23]. http://www.Rproject.org/

Riaño-Melo, O., Lizarazo, I., 2017. Estimación del volumen de madera en árboles mediante polinomioúnico de ahusamiento [Estimation of the volume of wood in trees by means of a single taper polynomial]. Colombia Forestal, 20 (1): 55-62.

Romahn-Delavega, C.F., RamíRez-Maldonado, H., Treviño, J.L., 1994. Dendrometría. México: Universidad Autónoma de Chapingo. 354 p.

Rosenqvist, A., Milne, A., Lucas, R., Imhoff, R., Dobson, C., 2003. A review of remote sensing technology in support of the Kyoto Protocol. Environmental Science \& Policy, 6: 441-455. https://doi.org/10.1016/S14629011(03)00070-4

Rzedowski, J., Calderón-de Rzedowski, G., 2003. Flora del Bajio y de regiones adyacentes [Flora of the Bajío and adjacent regions]. Xalapa: Instituto de Ecología, A.C. y la Comisión Nacional para el Conocimiento y Uso de la Biodiversidad. $344 \mathrm{p}$.

Sina-Conagua, 2021. Regiones hidrológicas. Reporte [Hydrological regions. Reports]. Sistema Nacional de Información del Agua-Comisión Nacional del Agua. México. [cit. 2021-06-08]. http://sina.conagua.gob.mx/ sina/index.php? $\mathrm{p}=32$

Stanturf, J.A., Palik, B.J., Dumroese, R.K., 2014. Contemporary forest restoration: A review emphasizing function. Forest Ecology and Management, 331: 292323. https://doi.org/10.1016/j.foreco.2014.07.029

TAYlor, A.H., HalPERn, C.B., 1991. The structure and dynamics of Abies magnifica forests in the southern Cascade Range, USA. Journal of Vegetation Science, 2: 189-200.

Timothy, D., Onisimo, M., Cletah, S., Adelabu, S., Tsitsi, B., 2016. Remote sensing of aboveground forest biomass: A review. Tropical Ecology, 57 (2): 125-132

Torre-Tojal, L., Bastarrik, A., Barrett, B., SanchezEspeso, J.M., LopeZ-Guede, J.M., GraÑa, M., 2019. Prediction of aboveground biomass from low-density LiDAR data: validation over P. radiata data from a region North of Spain. Forests, 10: 819 https://doi.org/10.3390/ f10090819

TuCKER, C.J., 1979. Red and photographic infrared linear combinations for monitoring vegetation. Remote 
Sensing of Environment, 8: 127-150. https://doi. org/10.1016/0034-4257(79)90013-0

Valiente-Banuet, A., Casas, A., Alcántara, A., Dávila, P., Flores-Hernández, N., Arizmendi, M.C., Villaseñor, J.L., Ortega-Ramírez, J., 2000. La vegetación del Valle de Tehuacán-Cuicatlán [The vegetation of the TehuacánCuicatlán Valley]. Boletín de la Sociedad Botánica de México, 67: 24-74. https://doi.org/10.17129/botsci.1625

Vásquez-Grandón, A., Donoso, P.J., Gerding, V. 2018.
Forest degradation: When is a forest degraded? Forests, 9: 726. https://doi.org/10.3390/f9110726

Wani, A.A., Joshi, P.K., Singh, O., 2015. Estimating biomass and carbon mitigation of temperate coniferous forests using spectral modeling and field inventory data. Ecological Informatics, 25, Suppl. C: 63-70.

Received July 16, 2021 Accepted November 13, 2021 